1982].

\title{
THE PUBLIC/PRIVATE DICHOTOMY: POLITICAL DISAGREEMENT AND ACADEMIG REPUDIATION
}

\section{ROBERT H. MNOOKIN $†$}

The distinction between public and private connects with a central tenet of liberal thought: the insistence that because individuals have rights, there are limits on the power of government vis-a-vis the individual. Public and private are the descriptive Iabels I will use in this essay to distinguish spheres or clusters of activities that are presumptively outside the legitimate bounds of government coercion and regulation (the private sphere) from those where government has a legitimate role (the public sphere).

At the outset, I should make clear that this dichotomy does not imply that attaching the label "private" to an activity signifies that government has no legitimate role, or that the characterizing of a realm as "public" means that anything goes. In the private sphere, some sort of legal framework and state involvement is often essential, if only to inhibit force and fraud and enforce contracts. "Nonetheless, under the terminology proposed here, the label "private" would carry with it a strong presumption that it is not legitimate for the government to be paternalistic or highly regulatory. It connotes, to use Justice Marshall's language, "a sphere of private autonomy which government is bound to respect." 1 In the public sphere, there would be no such presumption. This does not mean, of course, that in the public realm any governmental action is appropriate. Not all of an individual's rights are encompassed in the private sphere. Indeed, most civil rights have to do with an individual's participation as a citizen in public activities relating to governance, whether as political pamphleteer, voter, or speechmaker.

Given these definitions, the dichotomy between public and private can bring into focus two questions central to political theory and moral philosophy: (1) Should certain activities be considered "private," and thus at least presumptively beyond the legitimate sphere of regulatory, paternalistic governmental power? (2) If so, what activities should be considered "private" and why? I pose these questions not with the expectation of answering them. In-

$\uparrow$ Professor of Law, Stanford University. A.B. 1964, LL.B. 1968, Harvard University. This essay was written while I was a Fellow at the Center for Advanced Study in the Behavioral Sciences.

1 PruneYard Shopping Center v. Robbins, 447 U.S. 74, 93 (1980) (Marshall, J., concurring). 
stead, I will describe and contrast the answers to these questions offered by those on the contemporary scene in American political life with the answers implicit in American legal scholarship-at least as evidenced by papers presented at this symposium.

I.

Let's start with the political scene at large. It appears to me that across a broad political spectrum there is a consensus that the power of government should be bounded and that certain "private" activities should be presumptively beyond the bounds of legitimate government regulation or coercion. Put another way, I suspect that most liberal Democrats and conservative Republicans share a commitment to the idea of private as I have defined the term. The rub comes with the second question, however. What are the dimensions of the private realm? There appears to be no similar consensus about what activities should be considered private. Indeed, the very activities that are labeled private by liberal Democrats are considered public by conservative Republicans, and vice versa. These differences can be dramatically exposed by asking for the dimensions of the "public" and the "private" spheres in the realm of sexual expression and in the pursuit of economic goods.

Liberal Democrats would certainly attach the label "private" to a broad range of sexual activities involving consenting adults. They oppose attempts to regulate or withhold access to contraceptives or abortions. They disfavor the use of law, especially criminal law, to channel sexual activities exclusively into marriage, and to enforce sexual fidelity. They favor the repeal of those remaining statutes prohibiting consensual nonmarital sex or private consensual homosexual acts. They have pressed to "deregulate" marriage, arguing that individuals should be free to choose whether to marry, and what the terms of the marriage should be. They want to blur or eliminate the legal differences between marriage and cohabitation, and have pressed to extend legal protection to cohabitants, particularly to those who have made cohabitation agreements. In short, liberal Democrats would characterize a broad range of activities concerning sexuality and marriage as "private." They argue that in this sphere the state should facilitate private ordering and avoid regulation, especially regulation based on moralistic or paternalistic grounds.

Conservative Republicans do not view this realm as "private" and instead favor legal regulation. The family is a primary social institution, and conservatives tend to see it as entirely appropriate 
to use the legal system to impose the ideal of a monogamous, heterosexual marriage. Family stability is considered indispensable for the stability of society and civilization. Strict laws are endorsed because they can possibly deter marriage break-ups and protect children. Deterrence aside, such laws are seen as appropriate affirmations of fundamental social values and are also said to be necessary for the protection of the individuals involved.

With respect to economic activity, liberal Democrats and conservative Republicans swap positions. Conservatives emphasize the importance of private property, and see the market as an institution that appropriately rewards talent and contributes to economic efficiency. Various governmental programs to redistribute economic resources are generally disfavored as interfering with private enterprise. State interference with "free" consumer choice in the marketplace is opposed. Conservatives view government interference with dominion over what has been acquired through the market as suspect if not illegitimate, favoring strong legal protection for private property. Regulations to guard against occupational hazards or to protect consumers from their own "ignorance" are seen as paternalistic, and are generally opposed. Conservatives generally disfavor minimum wage laws and environmental regulations.

Liberal Democrats, on the other hand, view the economic sphere as quintessentially public. Progeny of the New Deal, they have limited faith in a market economy and are fundamentally suspicious of the distribution of resources it brings about. Government is seen as having affirmative obligations: (1) to protect consumers and the environment from exploitation by business interests; (2) to use tax policies and welfare policies to redistribute economic resources in favor of the less fortunate; and (3) to promote economic activity through macroeconomic policy. While most would not favor centralized planning or government ownership of the primary means of production, liberal Democrats are what Ronald Dworkin has called "reluctant capitalists" 2-they view active government intervention as essential to maintaining their faith in the marketplace.

It is worth noting that at times both the right and the left have been reluctant to trust the legislature with the task of defining the dimensions of these spheres. This is consistent, of course, with familiar arguments that legislative intrusion into the private realm may offend rights guaranteed by the Constitution. Such fears are easy to understand. The conservative perhaps suspects that an envious majority may be tempted to "soak the rich" and adopt pro-

. . 2 Dworkin, Liberalism, in Public and Parvate Morality I33 (S. Hampshire ed. 1978). 
tective legislation that interferes with the "free" pursuit of economic liberty. The liberal Democrat, on the other hand, fears that a rabid and moralistic minority may succeed in pressuring a timorous legislature to maintain or readopt restrictive laws that ratify sexual orthodoxy. The federal courts have been responsive to each, although at different times. During the four decades before 1937 the Supreme Court expressed solicitude for private property and freedom of contract and erected a now dismantled constitutional bulwark against attempts to regulate the economic sphere. And during the last sixteen years, the Court has used judicial powers once again to demarcate a private realm, this time in connection with contraception and abortion.

Notwithstanding the 1980 elections, the trends of the last fifty years-both legislative and judicial-certainly suggest that the economic realm has generally come to be seen as more public, while the sphere of activities centering around intimate association is viewed as more private. In 1937, the Supreme Court abandoned the economic realm to the legislature. ${ }^{3}$ Since 1930 , the share of GNP represented by the local, state, and federal governments has increased dramatically-today it represents about one fifth. ${ }^{4}$ The explosive increase since World War II in the size and power of the Washington, D.C., bar ${ }^{5}$ perhaps best symbolizes the increase in the importance of the government in the economy and the degree of economic regulation of one sort or another.

During the same period, the deregulation of marriage and sexual activities has been at least as striking. Until recently, marriage and divorce laws attempted to restrict private ordering severely. Substantial limitations were imposed on the power of parties to enter into prenuptial or nuptial agreements. Divorce was granted only after an official inquiry by a judge, who had to determine whether "appropriate grounds"-very narrowly defined in terms of marital offenses-existed. When a divorce was granted, the state asserted broad authority to structure the economic relationship of the spouses and to maintain regulatory jurisdiction over the children and their relationship to their parents. ${ }^{6}$ In 1965, no state permitted

3 See West Coast Hotel v. Parrish, 300 U.S. 379 (1937).

4 Total Output, Income and Spending, Econ. IndiCATons, Jan. 1982, at ${ }^{*}$. GNP in the fourth quarter of 1981 was $\$ 2984.9$ billion. Total government purchases of goods and services (federal, state, and local) were $\$ 615.7$ billion, or about one fifth (20\%). Id.

5 See Legal. Trmes, June 9, 1980, at 26-29. Between June, 1979, and June, 1980, 20 new firms opened offices in Washington.

6 Mnookin \& Kornhauser, Bargaining in the Shadow of the Law: The Case of Divorce, 88 YALE L.J. 950, 952-53 (1979). 
no-fault divorce upon the petition of one spouse. As of August 1, 1980 , only two states still limited divorce to traditional "fault" grounds. ${ }^{7}$ Today no state can outlaw the distribution of contraceptives $^{8}$ or prohibit first-trimester abortions. ${ }^{9}$ Nonetheless, a comparison of the platforms of the two national political parties in $1980,{ }^{10}$ the results of that presidential election, the continuing controversies concerning abortion, homosexual rights, and the Equal Rights Amendment, and signs of some revival of religious commitment, caution against confident extrapolation of past trends into the future.

Without trying to guess how public and private will be defined in the future, or whether any distinction will remain viable, it is interesting to ask why political values are clustered as they are. What lies behind each side's categorizations? What is the historical foundation for each and how deep is it? Does either cluster represent a stable basis for predicting the shape of American politics in the coming decade?

These contrasting clusters of values also raise fascinating issues at the level of political philosophy. Does it make sense to think there is a shared commitment to the liberal ideal of a private realm, when political opponents each pour such different content into the concept? Are either (or both) of these contrasting clusters intellectually coherent? Or does the contemporary conservative position represent nothing more than the illegitimate, and now aging, offspring of a union between John Calvin's morality and Adam Smith's economics? Is the liberal Democrat guided by an inconsistent vision that blends together in equal measure the teachings of John Stuart Mill, Hubert Humphrey, and Alex Comfort? Are each guilty, as Daniel Bell suggests, of applying a "double standard"? 11

In thinking about these issues, I find Ronald Dworkin's discussion of contemporary conservatives and liberals both helpful and suggestive. He posits that conservatives hold a particular concept

7 See State Divorce Law Chart, [Reference File] FAMr. L. REP. (BNA) 400iii (July 20, 1982). The two states are Illinois and South Dakota.

8 Eisenstadt v. Baird, 405 U.S. 438 (1972).

9 Roe v. Wade, 410 U.S. 113 (1973).

10 Republicans called for the appointment of anti-abortion federal judges, and opposed passage of the Equal Rights Amendment. Democrats emphasized full employment and job creation, while Republicans promised tax cuts, increased arms spending, and a balanced budget. The Democratic and Republican party platforms are summarized in N.Y. Times, Aug. 14, 1980, at B4, col. 1 and July 16, 1980, at A1, col. 3 .

11 D. Beul, The Cultural Contradictions of Capitarism 275 (1976). Bell observes that the right wants economic freedom, but moral regulation, while contemporary liberals "want economic regulation and moral freedom." Id. 
of virtue. For them, it is appropriate to use the "processes of legislation to reaffirm, as a community, its public conception of virtue." 12 Freedom in the economic marketplace, on the other hand, is defended for both instrumental and deontological grounds. According to conservatives, not only does the market most efficiently produce the appropriate bundle of goods and services, it also achieves distributional fairness by assigning "greater rewards to those who, because they have the virtues of talented industry, supply more of what is wanted by the other members of the virtuous society." 13 The liberal, according to Dworkin, rejects the notion that it is appropriate to legislate preferences concerning sexual behavior into public morality. Instead, the state should be neutral with respect to the content of the good life. The liberal is committed to an idea of equality that requires active government intervention in the marketplace, while leaving decisions about what should be produced in private hands. The liberal also combines a belief in political democracy with a view of rights that serve as "trump cards." 14

II.

Now let me turn to the symposium papers themselves as representatives of current legal scholarship and ask the same two questions: (1) Should there be a distinction between a private sphere, where presumptively the state should not regulate but instead maintain a laissez-faire attitude, and a public sphere where there is no such presumption? And (2), if so, what are the appropriate dimensions of the private and public realms? My thesis is straightforward. Unlike the world of American politics, where I see a consensus that the first question should be answered "yes," while the disagreement is at the second level, in the contemporary world of legal scholarship, the necessity of public/private dichotomy itself is being challenged. From the papers prepared for this symposium, it seems that these challenges come from very different directions.

Scholars in law and economics are implicitly challenging the dichotomy, notwithstanding the fact that the lawyer-economists are usually seen as champions of the liberal faith, particularly by "critical legal scholars." Professor Ellickson's paper ${ }^{15}$ comparing cities

12 Dworkin, supra note 2, at 137.

13 Id. 136.

$14 \mathrm{Id}$. (1982).

15 Ellickson, Cities and Homeowners Associations, 130 U. PA. L. Rev. 1511 
with "private" intermediaries, especially homeowners associations, exemplifies this challenge. Ellickson finds that homeowners associations, which are considered "private," look very much like cities, which are "public." For both entities, Ellickson asks what set of voting rules and standards of judicial review can best deal with the possibility of a majority adopting redistributive policies that disadvantage a "captive" minority.

Ellickson suggests that the disparities in legal treatment of these public and private entities should be reduced in two important respects: (1) Homeowners associations, like cities, should be subject to "taking clauses." (2) Cities, like homeowners associations, should have great flexibility in allocating voting power to reflect the economic stakes in local policies. ${ }^{16}$ In the concluding part of his paper, Professor Ellickson suggests that there is, no reason $\cdot a$ priori to favor or disfavor "public" intermediaries as compared to "private" intermediaries, such as ordinary corporations. He disagrees with Professor Frug that cities are in fact "powerless" or disadvantaged when compared to private intermediaries. While Frug proposes a coalition to press for the reforms necessary to place cities on the same legal footing as private intermediaries, Ellickson will join in pushing for expansion of city business powers only if Frug supports reforms to remove existing tax subsidies for cities.

I suspect that when Professor Ellickson began thinking about these issues he did not intend to obliterate the distinction between public and private. His own analysis simply led him to policy conclusions that a sharp dichotomy makes little sense in this context. Nonetheless, I think the mode of analysis used by lawyereconomists (myself included) systematically pushes in the direction of making the public/private distinction unimportant. Let me briefly explain why.

Lawyer-economists view legal rules and procedures as policy instruments. To use philosophical jargon, they are consequentialists-they evaluate alternatives by comparing consequences. Concerned with the consequences of alternative legal rules, they find the distinction between public and private irrelevant. Legal rules may potentially affect behavior in any realm of human life: in

$16 \mathrm{He}$ does not suggest that there are no relevant differences between cities and homeowners associations. Because homeowners associations (unlike cities) can have no involuntary members when formed, Ellickson concludes that courts should view with suspicion amendments to the original governing documents (because the change may represent an ex post attempt to change the rules to redistribute coercively), but should give deference to the original documents themselves (because the market price will appropriately reflect the ex ante risks of redistribution, thus creating an appropriate incentive for the developer). See id. 1526-27. 
comparing alternative legal rules, the consequences are what count, no matter what the "sphere."

This limited analytical perspective, while often noted, is not usually the focus of the attack on the law and economics approach by critical legal scholars. These critics more often challenge what they see as the implicit or explicit values used by lawyer-economists to evaluate and compare the consequences of alternative policies. They perceive a bias in favor of "efficiency" as opposed to fair distribution. Sophisticated critics also attack the use of individual preferences as the basis for choice. They point out that economics has no theory to explain how preferences are generated or changed. They challenge the individualistic bias of economic thought, and the assumption that existing individual preferences can be taken as given, or exogenous.

Certainly, such critics usually place economic analysis in the liberal tradition because it is individualistic and market-oriented. But for my purposes, at least, the more striking feature of the approach of lawyer-economists is not liberal-in the sense in which I am using the word-because they do not allow for a private sphere, presumptively beyond the legitimate range of coercive state power. Everything is up for grabs-it all turns on how the policy analysis comes out in terms of consequences. Presumably, if the expected consequences of allocating voting power only to property owners were "preferable" to alternatives by some measure of social utility, then that scheme would be the optimum policy. Similarly, the decision whether consensual homosexual activity should be decriminalized, or whether government should impose a minimum wage does not turn on the characterization of the realm of activity. There are no deontological rights that make it illegitimate for government to adopt particular sorts of legal rules.

If Ellickson's challenge to the public/private dichotomy is implicit, Professor Karl Klare's certainly is not. ${ }^{17}$ It is not surprising that Klare, who associates himself with the critical legal studies movement, attacks the dichotomy, because the one unifying tenet of this group is a commitment to showing the contradictions of liberal thought. Professor Klare denies the legitimacy of searching for a sphere of activities defined as being "private" and thus beyond the state's power. For Klare, it seems there is no such thing as "private." All is public because it is impossible to conceive of social and economic life apart from government and law. Seeing

17 See Klare, The Public/Private Distinction in Labor Law, 130 U. PA. L. REv. 1358 (1982). 
the public/private distinction as part of the intellectual apparatus of liberal thought, Klare believes public/private rhetoric tends to "channel democratic aspirations into the framework of individualistic rights" 18 and acts as a cover used to justify "class hierarchy and domination." to Posing as "an analytical tool," the public/ private distinction "functions more as a form of political rhetoric used to justify particular results"; ${ }^{20}$ to justify "the private appropriation of socially-created wealth"; 21 "to sanction private control of investment in resource-allocation decisions of societal consequence, and generally to legitimize the 'free' market as an institution." 22 Klare does more than suggest that the "rise of the regulatory state" and the "primacy of vast corporate entities" ${ }^{23}$ constantly erode the meaningfulness of the distinction. His more general thesis is that "the social function of the public/private distinction is to repress aspirations for alternative political arrangements." 24

I am curious whether Professor Klare's disdain for the distinction between public and private extends to the sphere of intimate relations. Should individuals have substantive rights that can shield their consensual sexual conduct from government regulation? Which private economic interests "captured" state power to deregulate divorce law, to decriminalize contraception and abortion, and in about fifteen states, consensual homosexual activity as well? Has the result of these changes been to perpetuate class domination and inequality in social life? If he approves of these changes, as I suspect he does, then is his critique of the dichotomy limited to its application in the sphere of economic regulation in general, and labor law in particular? Or does he think it is equally meaningless and contradictory to insist on a private realm with respect to consensual sexual relations?

Professor Klare's discussion of benShalom $v$. Secretary of the Army ${ }^{25}$ comes close to suggesting that the public/private distinction is equally meaningless in the sphere of intimate relations. The district court in that case ordered the reinstatement of an Army

18 Id. 1419.

19 Klare, Preliminary Memorandum for The Public/Private Distinction in Labor Law, supra note 17 , at 2 (Dec. 29, 1981) (on file at University of Pennsylvania Law Review).

$20 \mathrm{Klare}$, supra note 17, at 1361.

21 Klare, Labor Law as Ideology: Toward a New Historiography of Collective Bargaining Law, 4 INDus. Rex. L.J. 450, 456 n,19 (1981).

$22 I d$.

23 Id.

24 Klare, supra note 17 , at 1361.

25489 F. Supp. 964 (E.D. Wis. 1980). 
reservist who had been discharged because she was a homosexual. Klare applauds the benShalom holding as "visionary." 26 However, he would plainly prefer to base the result not on the need to protect an individual's "privacy" from public intrusion, but instead on a right of the public to a "sexually pluralistic environment." 27 What is ambiguous, however, is whether his proposed "public right" would be the entire foundation or would instead simply. supplement an individual's privacy right. He writes: "Ideally, the law should not only create zones of privacy and protect victimized employees, but it should also recognize a public right of employees to work in a sexually pluralistic environment." 28 Beneath this ambiguity lurks a troubling dilemma for Klare. On the one hand, any reliance on an individual's right to personal privacy seems inconsistent with Klare's total rejection of the public/private distinction. On the other hand, a complete reliance on his undefined "public right" hardly offers much protection for sexual autonomy. What limits are there to Klare's proposed "public right . . . to work in a sexually pluralistic environment," and who defines those limits? Gan a majority force an individual to change her sexual orientation in order to make the environment more pluralistic? Conversely, can the "public" restrain consensual sexual relations when a majority thinks there is "enough" sexual pluralism? Klare's "public right" approach leads to contradictions and indeterminacies of just the sort that he condemns.

Professor Brest's approach ${ }^{29}$ is different from that of Professor Klare-he does not argue that the state action doctrine is simply a veil used by industrialists to dominate the proletariat. But he appears to share Professor Klare's view that there can be no fundamental distinction between government and private action. The implication of his article is that there can be no "private" sphere that should presumptively be beyond the reach of policy and politics.

Professor Brest's immediate target is Justice Rehnquist's brand of constitutional interpretation as revealed in Flagg Brothers $v$. Brooks. ${ }^{30}$ He examines Rehnquist's attempt to define state action for the purpose of distinguishing a public sphere (where due process protections must apply) from a private sphere (where the legislature,

26 Klare, supra note 17 , at 1387.

27 Id.

28 Id. (emphasis added).

29 Brest, State Action and Liberal Theory: A Casenote on Flagg Brothers v. Brooks, 130 U. PA. L. REv. 1296 (1982).

30436 U.S. 149 (1978). 
not the courts, is responsible for defining appropriate procedures), and finds the result inconsistent with the broadest implications of Rehnquist's positivism. Professor Brest's more general message is that the Hobbesian "positivist" version of liberal thought fails to provide a coherent basis for the state action doctrine. For positivists, Brest says, there can be no principled dichotomy because the state itself creates the laws that define "private" rights: "since any private action acquiesced in by the state can be seen to derive its power from the state, which is free to withdraw its authorization at will, positivism potentially implicates the state in every 'private' action not prohibited by law." 31 Therefore, everything collapses into the policy issue of what laws best serve social needs. Under the natural law version of liberalism (although not the focus of Brest's paper), state action doctrine fares no better. Although natural law and state action doctrine are "mutually sympathetic," 32 state action doctrine "reflects and reinforces . . . a natural regime of property rights" that is biased in favor of business. ${ }^{33}$ Brest suggests his conclusion about both branches of liberal theory as follows: "Because it is not possible to specify the essence or scope of the government function or the exclusivity with which it is performed with any degree of specificity, the public function doctrine invites manipulation." 34 Therefore, it would seem that for Professor Brest, as for Professors Ellickson and Klare, there is no principled way to justify a private realm.

\section{III.}

Now let us step back and see where we have been. In the contemporary world of American politics, there appears to be a consensus that there are spheres of activity within a "private" realm where there should be a strong presumption against paternalistic government regulation, and individuals should be free to decide for themselves what to do. The disagreement is over which activities belong in the public and private spheres. Liberal Democrats and conservative Republicans both use the public/private dichotomy to distinguish the legitimacy of governmental regulation in the realm of sexual expression from the sphere involving the pursuit of economic goods, but they would contradict each other in attaching the labels to each set of activities. It's as if there were agree-

\footnotetext{
31 Brest, supra note 29 , at 1301 .

32 Id. 1300.

33 Id. 1330.

34 Id. 1329 (footnote omitted).
} 
ment that a river separates Manhattan from Brooklyn, but disagreement about which borough is Manhattan and which is Brooklyn. From my examination of three of the principal papers presented at this symposium, however, I suggested that scholars are challenging the legitimacy of the dichotomy itself-the idea that there is a sphere of private autonomy that the state should respect.

Now there is, of course, no necessity that one accept the liberal tenet that there should be limits on the power of government vis-avis the individual. Historical and comparative analyses in no way suggest that the idea of a dichotomy between public and private has been widely accepted. In a theocratic state-the Ayatollah's Iran seems a contemporary example-there is no private realm, for the state must enforce God's morality in all human interaction. Other modern regimes premised on more secular ideologies also reject the notion that there is a private sphere beyond the realm of governmental control. In China, sexual morality is a matter of public concern. Premarital intercourse is against the law; responsible citizens are under an obligation to report an offending couple to the authorities so that they can be brought in for thought reform. Moreover, the family limitation program involves the authorities in the sexual lives of married couples, who are permitted to have a second child only if they agree either to be sterilized immediately afterwards, or to have an abortion if there are any further conceptions. Forced abortions are used to discipline offenders. ${ }^{35}$

The basic claim with which my talk began is that the public/ private dichotomy relates to fundamental questions of political theory and moral philosophy. To what extent should individual interests be subordinated to collective control? To what extent should we have collective control over individual behavior? Are there limits? What should they be? I repeat these questions, and I address them particularly to those committed to rejecting the intellectual tyranny of liberalism. Is your rejection total, or is your disagreement really limited to the attempts to characterize economic activities as private? Are you really closet liberals when the public/ private dichotomy is used to defend autonomy in the sexual realm?

35 I learned about contemporary Chinese attitudes and practices from discussions with Marjorie Wolf, a Fellow at the Center for Advanced Study in the Behavioral Sciences, who is presently completing a book on the role of women in China. See also F. Butterfietd, Chrna: Alive in the Bitter Sea 227-28 (1982). 